\title{
How to Move China toward a Green-Energy Economy: From a Sector Perspective
}

\author{
Jie-fang Dong ${ }^{1,2,3,4}$, Qiang Wang ${ }^{1, *}$, Chun Deng ${ }^{4}$, Xing-min Wang ${ }^{1,3}$ and Xiao-lei Zhang ${ }^{1,2}$ \\ 1 State Key Laboratory of Desert and Oasis Ecology, Xinjiang Institute of Ecology and Geography, \\ Chinese Academy of Sciences, Urumqi 830011, China; dongjiefang-2005@163.com (J.D.); \\ Wxminmin1987@163.com (X.W.); zhangx1@ms.xjb.ac.cn (X.Z.) \\ 2 College of Resource and Environment Sciences, Xinjiang University, Urumqi 830046, China \\ 3 College of Resources and Environment, University of Chinese Academy of Sciences, Beijing 100049, China \\ 4 Department of Economics and Management, Yuncheng University, Yuncheng 044000, China; \\ dengchun-2005@163.com \\ * Correspondence: qiangwang7@outlook.com; Tel.: +86-0991-788-5420
}

Academic Editor: Daniel A. Vallero

Received: 19 March 2016; Accepted: 31 March 2016; Published: 6 April 2016

\begin{abstract}
With China's rapid economic growth, energy-related $\mathrm{CO}_{2}$ emissions have experienced a dramatic increase. Quantification of energy-related $\mathrm{CO}_{2}$ emissions that occur in China is of serious concern for the policy makers to make efficient environmental policies without damaging the economic growth. Examining 33 productive sectors in China, this paper combined the extended "Kaya identity" and "IPAT model" with the Log-Mean Divisia Index Method (LMDI) to analyze the contribution of various factors driving of energy-related $\mathrm{CO}_{2}$ emissions in China during 1995-2009. Empirical results show that the main obstacle that hinders China's transition to a green energy economy is the economic structure characterized by high carbon emissions. In contrast, the increased proportion of renewable energy sources (RES) and the improvement of energy efficiency play a more important role in reducing carbon emissions. Moreover, the power sector has a pivotal position in $\mathrm{CO}_{2}$ emissions reduction, primarily because of the expansion of electricity consumption. These findings suggest that policies and measures should be considered for various industrial sectors to maximize the energy efficiency potential. In addition, optimizing the industrial structure is more urgent than adjusting the energy structure for China.
\end{abstract}

Keywords: $\mathrm{CO}_{2}$ emissions; LMDI I; production sector; green-energy economy; China

\section{Introduction}

\subsection{Background information}

Climate change is one of the most challenging world issues in this century [1]. As the primary greenhouse gas (GHG), $\mathrm{CO}_{2}$ emissions contribute approximately $60 \%$ of the total greenhouse effect in the world [2,3]. Since 2007, China's $\mathrm{CO}_{2}$ emissions caused by energy consumption have overtaken USA's $\mathrm{CO}_{2}$ emissions for the first time and are ranked first in the world [4]. The rapid growth of energy consumption and the induced $\mathrm{CO}_{2}$ emissions have put much pressure on China. In response, China has made some unequivocal commitments to address $\mathrm{CO}_{2}$ emissions [5]. At the Climate Conference in Paris in 2015, the Chinese government defined a more ambitious scenario. For 2030, the carbon intensity must be reduced by $60 \%-65 \%$ ( $40 \%-45 \%$ for 2020$)$ of 2005 levels and new energy, including nuclear and Renewable Energy Sources (RES), must account for $20 \%$ in the energy matrix (15\% for 2020). To achieve these commitments, precise quantification of the $\mathrm{CO}_{2}$ emissions change in China is critical. The best way to succeed is to make policies that focus on the crucial drivers of $\mathrm{CO}_{2}$ emissions while avoiding inhabiting economic growth. 
From the perspective of different sectors, this paper addresses the topic of a green energy economy, focusing on $\mathrm{CO}_{2}$ emissions and investigates energy efficiency and the role of RES, which are regard as the main factors to offset increased $\mathrm{CO}_{2}$ emissions. Data were obtained from the World Input-Output Database (WIOD) and determined the period under consideration. WIOD provides National Input-Output tables and data on energy use and, $\mathrm{CO}_{2}$ emissions of 35 productive sectors that can be used in comparative analysis between the different sectors. Moreover, two obvious benefits are obtained through comparative analysis. On the one hand, it is possible to compare the effects of different sectors on $\mathrm{CO}_{2}$ emissions in a particular year. On the other hand, the shifting pattern of the contribution rates of each sector can be fully reflected from time series data. Subsequently, the energy policy based on the results of quantitative studies, which look at department subdivisions, has better maneuverability.

\subsection{Literature Review}

In the recent decade, much of the literature has probed the factors influencing $\mathrm{CO}_{2}$ emissions. There are primarily two approaches to the research: econometric analysis [6-15] and decomposition methods [16-31]. Compared with econometric analysis, the decomposition method has the following advantages: (1) it has a lower requirement in the time span of the data; (2) it is not bound by the economic theory; and (3) each influencing factor of $\mathrm{CO}_{2}$ emissions can been accurately identified in every year.

Decomposition analysis has been widely utilized to quantify the variations in energy consumption and $\mathrm{CO}_{2}$ emissions. There are primarily three categories of the decomposition approach: Structure Decomposition Analysis (SDA), Index Decomposition Analysis (IDA), and Production-theoretic Decomposition Analysis (PDA) [29]. Compared with the other methods, IDA is the most commonly used in energy and environmental studies owing to its obvious advantages such as theoretical foundation, adaptability, ease of use, and result interpretation [32,33]. Since the 1980s, literature on decomposition based on Divisia-type indices has been extremely prolific in various countries and regions, including India [34], Turkey [35], Korea [36,37], Brazil [26], Portugal [38], the Soviet Union [39], the European Union [40,41], Greece [42,43], Latin America [44,45], Italy [46], Spain [47], Ireland [48,49], and Mexico [45].

In China, decomposition analysis of emissions has also been extensively utilized. In general, these studies can be divided into three categories from the perspective of the object of study. The first category takes the aggregate $\mathrm{CO}_{2}$ emissions in China as the research object. For example, Wang et al. [24] applied an LMDI method to analyze the changes in aggregate $\mathrm{CO}_{2}$ emissions in China during 1957-2000. This study indicated that the decrease of $\mathrm{CO}_{2}$ emissions was mainly due to improved energy intensity. Zhang et al. [16] analyzed the nature of the factors that influence changes in energy-related $\mathrm{CO}_{2}$ emission from 1991 to 2006. This research discovered that energy intensity is the dominant contributor to the decline in $\mathrm{CO}_{2}$ emissions whereas economic activity is the most important contributor to increased $\mathrm{CO}_{2}$ emissions. Yuan et al. [50] used the SDA method to decompose China's aggregate $\mathrm{CO}_{2}$ emission into five different factors during 2002-2007. Zhang et al. [29] applied the LMDI method to decompose the changes in China's carbon emissions and carbon emission intensity from 1996 to 2010 and analyzed the decoupling relationship between carbon emissions and economic growth in China. $\mathrm{Xu}$ et al. [21] analyzed factors that influence carbon emissions due to fossil energy consumption in China to identify key factors for policies promoting carbon emission reductions. The second category decomposed $\mathrm{CO}_{2}$ emissions from a sector perspective. For instance, both Wang et al. [51] and Guo et al. [52] investigated the potential factors influencing the change in China's transportation $\mathrm{CO}_{2}$ emissions. Tian et al. [53] addressed the driving forces of GHG emission in the Chinese iron and steel industry for 2001-2010. Liu et al. [54] utilized decomposition and attribution analyze to analyzed the changes in carbon intensity in China's industrial sector. Fan et al. [55] identified the driving forces of emissions in the residential sector. Ouyang et al. [56] analyzed the change in energy-related $\mathrm{CO}_{2}$ emissions in China's industrial sector from 1991 to 2010. Lin et al. [57] evaluated the changes in $\mathrm{CO}_{2}$ 
emissions from energy consumption in China's food industry from 1986 to 2010. Lin et al. [58] analyzed the energy-related $\mathrm{CO}_{2}$ emissions and reduction potential in the Chinese non-metallic mineral product industry. The third category includes studies that used province-level data to characterize regional differences in the factors that influence carbon emissions. For example, Zhang et al. [28] studied the variation of $\mathrm{CO}_{2}$ emissions of primary energy consumption and its influencing factors in the Xinjiang Uygur autonomous region from 1952 to 2008. Wang et al. [59] investigated the driving forces governing $\mathrm{CO}_{2}$ emissions and their evolution in Jiangsu Province. Liu et al. [60] decomposed the energy-related GHG emissions from four Chinese mega-cities (Beijing, Tianjin, Shanghai and Chongqing) during 1995-2009.

Although decomposition analysis has been extensively applied in China, some gaps are highlighted in the literature. First, the majority of previous studies focused on aggregate emissions or specific sectors (e.g., industry, transport, food industry and residential sector); however little attention has been paid to sector disparities in the driving forces of emissions. Second, most of the previous literature has centered on the presentation of quantitative results without discussing the underlying causes. More importantly, much of the previous research has emphasized the negative effect of coal use in carbon emissions abatement but rarely discussed the promotion effect of RES to reduce carbon emissions.

To fill in the above gaps, this paper identifies the key drivers behind China's $\mathrm{CO}_{2}$ emissions and focuses on the sector disparities based on the extended version "Kaya identity" and IPAT equation $[45,61,62]$. Thirty-three sectors were considered, which coincides with the WIOD database. Moreover, based on the decomposition results, the underlying policies and measures implemented were evaluated, and the role of RES in the low-carbon process was discussed. Because of its adaptability, ease of use, and result interpretation, we utilized the Log-Mean Divisia Index Method I, which was proposed by Ang and Choi [63] and revised by Ang [32], to decompose the changes in $\mathrm{CO}_{2}$ emissions in China during 1995-2009, coinciding with the time period of the WIOD database.

\section{Methodologies and Data Definitions}

\subsection{Methodologies}

Based on the Kaya identity and IPAT equation, the impact of five explanatory factors was identified and quantified in this study, including the population factor $(P)$, economic activity factor $(E A)$, energy intensity factor $(E I)$, economic structure factor $(E S)$, and carbon intensity factor $(C I)$. The factor $P$ refers to the effects of population growth as a determinant for energy demand. The factor $E A$ expresses the effects of output per capita on $\mathrm{CO}_{2}$ emissions increment. The $E I$ factor, energy intensity, corresponds to energy consumption per unit of output. In this paper, the economic output per sector is derived from the Input-Output Tables and the output is transformed into 1995 constant prices. The ES factor is defined as the structural composition of China's economy. Finally, the CI factor describes the ratio of $\mathrm{CO}_{2}$ emissions and energy consumed. This factor represents the quality of the energy mix from the view of $\mathrm{CO}_{2}$ emissions.

The LMDI I analysis of total $\mathrm{CO}_{2}$ emissions from industrial sectors in China was conducted by the following equation (Equation (1)):

$$
C O_{2}=\sum_{i=1}^{n} P \times \frac{Y}{P} \times \frac{Y_{i}}{Y} \times \frac{E_{i}}{Y_{i}} \times \frac{C_{i}}{E_{i}}=\sum_{i=1}^{n} P \times E A \times E S_{i} \times E I_{i} \times C I_{i}
$$

where, $\mathrm{CO}_{2}$ indicates the total $\mathrm{CO}_{2}$ emissions from China; $P$ denotes the Population; $Y$ represents the total output; $Y_{i}$ indicates the output of sector $i$; $E_{i}$ represents the energy consumption of sector $i$; and $C_{i}$ is the $\mathrm{CO}_{2}$ emissions of sector $i$. 


$$
\begin{aligned}
& \Delta C O_{2}=C O_{2}^{t}-C O_{2}^{t-1}=\Delta P+\Delta E A+\Delta E S+\Delta E I+\Delta C I \\
& =\sum_{i=1}^{n} w_{i}^{t} \ln \frac{P^{t}}{P^{t-1}}+\sum_{i=1}^{n} w_{i}^{t} \ln \frac{E A^{t}}{E A^{t-1}}+\sum_{i=1}^{n} w_{i}^{t} \ln \frac{E S^{t}}{E S^{t-1}}+\sum_{i=1}^{n} w_{i}^{t} \ln \frac{E I^{t}}{E I^{t-1}}+\sum_{i=1}^{n} w_{i}^{t} \ln \frac{C I^{t}}{C I^{t-1}}
\end{aligned}
$$

The term $w_{i}^{t}$ is the estimated weight for the addictive LMDI I and this weight is defined as

$$
w_{i}^{t}=\frac{C O_{2 i}^{t}-C O_{2 i}^{t-1}}{\ln C O_{2 i}^{t}-\ln C O_{2 i}^{t-1}}
$$

\subsection{Database}

The data used in this study comes from the World Input-Output Database (WIOD). The World Input-Output Database has been developed to analyze the effects of globalization on trade patterns, environmental pressures and socio-economic development across a wide set of countries. The database covers 27 EU countries and 13 other major countries in the world for the period from 1995 to 2009 [64]. This database is heavily grounded upon official statistics from national statistical institutes and it was opened to the public in 2012 [47].

One of the advantages of this database is that it includes 35 industry sectors making it convenient to see which sector is the main driving factor of energy consumption, and moreover, of $\mathrm{CO}_{2}$ emissions. The WIOD environmental account offers information about energy consumption and $\mathrm{CO}_{2}$ emissions categorized by industry sectors, but only for the period of 1995-2009. We chose to use WIOD database because it allows a multi-sector analysis. It should be noted that the data are missing in two sectors: the Sales, Maintenance and Repair of Motor Vehicles and Motorcycles sector and the Private Household with Employed Persons sector. Therefore, there were 33 industry sectors included in this study. Table 1 shows these sectors.

Table 1. The 33 production sectors in China.

\begin{tabular}{cl}
\hline Code & \\
\hline 1 & \multicolumn{1}{c}{ Production Sector } \\
2 & Agriculture, Hunting, Forestry and Fishing \\
3 & Food, Beverages and Tobacco \\
4 & Textiles and Textile Products \\
5 & Leather, Leather and Footwear \\
6 & Wood and Products of Wood and Cork \\
7 & Pulp, Paper, Paper, Printing and Publishing \\
8 & Coke, Refined Petroleum and Nuclear Fuel \\
9 & Chemicals and Chemical Products \\
10 & Rubber and Plastics \\
11 & Other Non-Metallic Mineral \\
12 & Basic Metals and Fabricated Metal \\
13 & Machinery, nowhere else classified (n.e.c.) \\
14 & Electrical and Optical Equipment \\
15 & Transport Equipment \\
16 & Manufacturing, n.e.c.; Recycling \\
17 & Electricity, Gas and Water Supply \\
18 & Construction \\
19 & Wholesale Trade and Commission Trade, Except of Motor, Vehicles and Motorcycles \\
20 & Retail Trade, Except of Motor Vehicles and Motorcycles; Repair of Household Goods \\
21 & Hotels and Restaurants \\
22 & Inland Transport \\
23 & Water Transport \\
24 & Air Transport \\
25 & Other Supporting and Auxiliary Transport Activities; Activities of Travel Agencies \\
\hline
\end{tabular}


Table 1. Cont.

\begin{tabular}{cl}
\hline Code & \\
\hline 26 & Post and Telecommunications \\
27 & Financial Intermediation \\
28 & Real Estate Activities \\
29 & Renting of M\&Eq and Other Business Activities \\
30 & Public Admin and Defense; Compulsory Social Security \\
31 & Education \\
32 & Health and Social Work \\
33 & Other Community, Social and Personal Services \\
\hline
\end{tabular}

In particular, the data of energy consumption and the $\mathrm{CO}_{2}$ emissions came from the Environmental Accounts of WIOD. The outputs of the 33 industry sectors were derived from the National Input-Output Tables. Population data came from the China Statistical Yearbook (CSY) [65]. The electricity mix data were derived from the China Energy Statistical Yearbook (CESY) [66].

\section{Empirical Results and Analyses}

The variation of $\mathrm{CO}_{2}$ emissions during 1995-2009 is shown in Figure 1 consecutively. In the upper section of the figure, the contribution of the influencing factors appears in a bar graph, while the changes in total $\mathrm{CO}_{2}$ emissions appear as a line. The variation of $\mathrm{CO}_{2}$ emissions appear as percentages at the bottom of Figure 1 for each factor. The total variation is explained by the sum of these factors in absolute values. From 1996 to 2009, CO 2 emissions increased annually, except in 1997, 1999, and 2000. For the 2001-2004 sub-periods, the variation rate for emissions increased; however, it decreased for the period of 2005-2009.

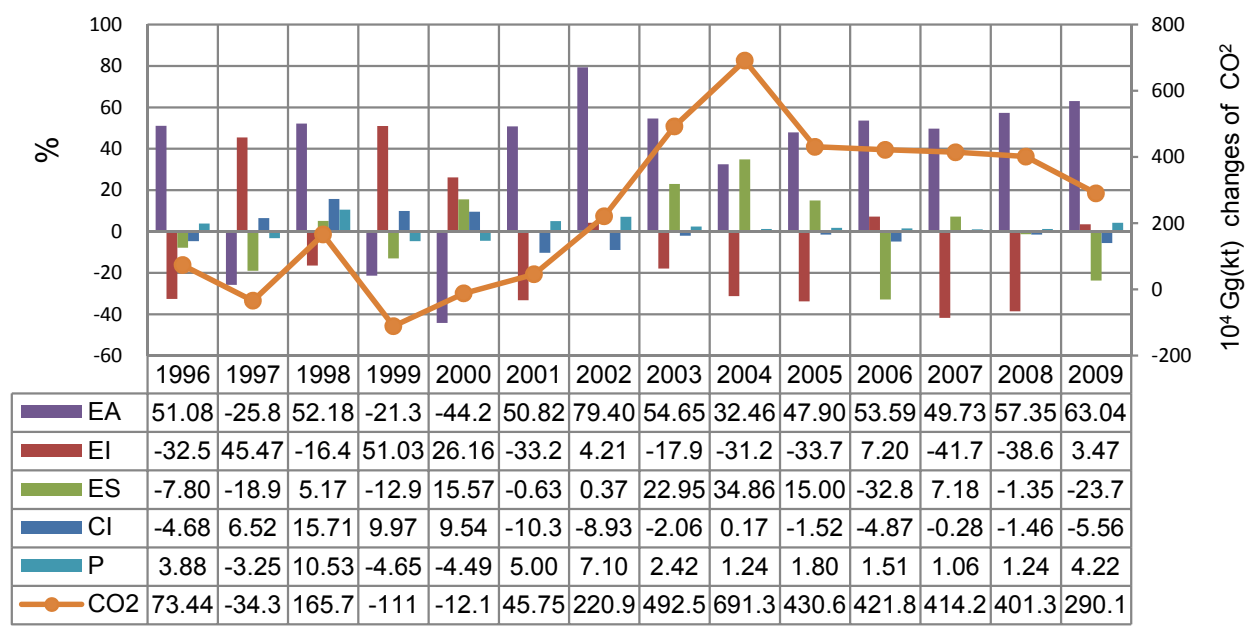

Figure 1. Decomposition based on contribution rate of $\mathrm{CO}_{2}$ emission in China.

\subsection{Economic Activity (EA)}

The results in Figure 1 show that the EA factor is the dominant driving force in increased $\mathrm{CO}_{2}$ emissions. Compared to Spain [47], the factor EA in China plays a more important role in the increment of $\mathrm{CO}_{2}$ emissions. It indicates the rapid growth of economic activity in a developing country leads to more $\mathrm{CO}_{2}$ emissions. As Figure 1 shows, the weights of the EA contributions were negative in 1997, 1999 and 2000. This result must be viewed cautiously. It does not mean the EA factor decreased $\mathrm{CO}_{2}$ emissions in these three years. Comparing the change in $\mathrm{CO}_{2}$ emissions with the contributions of EA, it can be found that the total $\mathrm{CO}_{2}$ emissions declined in 1997, 1999, and 2000 while the EA 
factor inhibited the reduction progress. In fact, it indicates that in these three years, the EA factor also increased $\mathrm{CO}_{2}$ emissions.

According to the decomposition results, $\triangle E A$, the $\mathrm{CO}_{2}$ emission changes from economic activity increased by 7.2 billion tons during 1995-2009, which is 2.1 times the total $\mathrm{CO}_{2}$ emissions changes. Over the study period, China's economy witnessed sustained takeoff and the average growth rate reached 13.7\%. Even during the Asia financial crisis in 1997 and the international financial crisis in 2009, the growth rates were $9.4 \%$ and $8.1 \%$, respectively [29]. However, it should be noted that this rapid economic growth was supported by tremendous energy consumption. As shown in Figure 2, from 1995 to 2009, the energy consumption in China increased from 45 million terajoule (TJ) to 114 million TJ. Correlation analysis showed that the two variables of GDP and energy consumption are significantly correlated at 0.01 level and the Pearson correlation coefficient is as high as 0.969 .

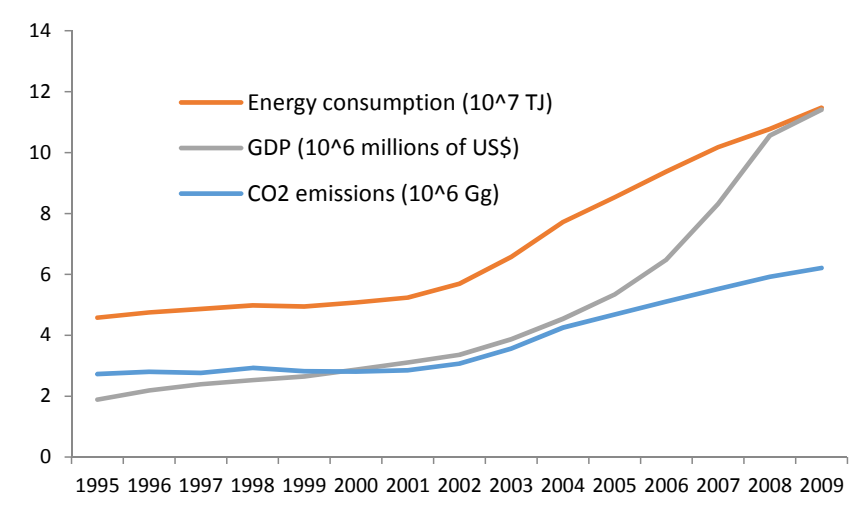

Figure 2. The trajectory of energy consumption and GDP and $\mathrm{CO}_{2}$ emissions in China.

As shown in Figure 2, the growth rates of $\mathrm{CO}_{2}$ emissions were relatively high during 2001-2004. This period coincides with China's 10th Five-Year Plan, which emphasized the growth of export. The Chinese accession to the World Trade Organization (WTO) in 2001 has stimulated the formation of an export-led economic mode in China. Meanwhile, the progress of urbanization and industrialization also increased energy consumption that in turn promoted $\mathrm{CO}_{2}$ emissions. It has been seen from Figure 2 that since 2005, the growth rate of $\mathrm{CO}_{2}$ emissions has slowed gradually. This is due to the implement of the "Medium and Long Term Energy Conservation Plan," which was launched by the National Development and Reform Commission (NDRC) in May 2005. In Figure 2, the decoupling of GDP and $\mathrm{CO}_{2}$ emissions is observed since 2005.

\subsection{The Energy Intensity Factor (EI)}

As for the EI factor, it must be emphasized that EI behaved as the major inhibiting factor for $\mathrm{CO}_{2}$ emissions, which means that improved efficiency of energy use plays a significant role in diminishing $\mathrm{CO}_{2}$ emissions. As Figure 1 shows, during 1995-2009, EI does not follow a regular pattern; in most years, the values are negative, which contributes positively to reducing $\mathrm{CO}_{2}$. However, in 1997, 1999, 2000, 2002, 2006, and 2009, the values are positive. Moreover, combined with the changes in $\mathrm{CO}_{2}$ emissions, we divided the six years into two different categories and analyzed them respectively. The first category includes 1997, 1999, and 2000. In these years, the changes in $\mathrm{CO}_{2}$ emissions are negative which implied that the positive value of EI positively contributes to diminishing $\mathrm{CO}_{2}$. In the second category, in 2002, 2006, and 2009, the EI factor increased $\mathrm{CO}_{2}$ emissions. This is mainly explained by two reasons: China's accession to the WTO and the process of urbanization and industrialization in China.

To find a regular pattern of this factor, the disaggregated values for the 33 sectors included in the WIOD are shown in Table A1. According to Table A1, the behavior of the EI factor can be analyzed 
by sectors. Through comparative analysis between the different years and sectors, some interesting results are obtained.

In most years, the value of EI was negative for $\mathrm{CO}_{2}$ emissions except 2002, 2006, and 2009. This shows that in most years during the study period, the factor of EI play a critical role in decreasing $\mathrm{CO}_{2}$ emissions. In these three years, a series of energy-saving and emission-reduction policies were launched and energy saving advanced technology was widely applied. Specifically, the Laws of Saving on Energy Resources in Peoples' Republic of China (PRC) and the Notice on Further Support for the Development of New Energy and Renewable Energy were implemented in 1998. In addition, the Renewable Energy Law of PRC was published in 2005. The implementation of these policies played a positive role in improving energy efficiency, reducing carbon emissions, protecting and improving the environment.

In terms of sectors, the Electricity, Gas and Water Supply sectors and the Basic Metals and Fabricated Metal sectors are the two key economic sectors that influence the symbol of the EI effectively, followed by the sectors of Chemicals and Chemical Products, Other Non-Metallic Minerals, and Mining and Quarrying. Furthermore, we calculated the energy intensity in the 33 sectors and found the average energy intensity of Electricity, Gas and Water Supply sector was $230.5 \mathrm{TJ} /$ million 1995 US dollars, the highest and far more than the other sectors that we have mentioned above. This further illustrates that the Electricity, Gas and Water Supply sector plays a crucial role in diminishing China's total carbon emissions. Therefore, from an energy policy perspective, efforts should not only focus on the power sector but also on those sectors that are major electricity consumers.

Figure 3 represents the main electricity consuming sectors. Deeper research reveals the main electricity consuming sectors include Basic Metals and Fabricated Metal (which share 22.7\% in total electricity consumption, average value between 1995 and 2009), in addition to Chemicals and Chemical Products (12.4\%), Mining and Quarrying (7.4\%), Other Non-Metallic Minerals (6.9\%) and Agriculture, Hunting, Forestry and Fishing (4.8\%). Therefore, any improvement in energy efficiency in these sectors will help to cut energy consumption in the power sector, thus reducing carbon emissions.

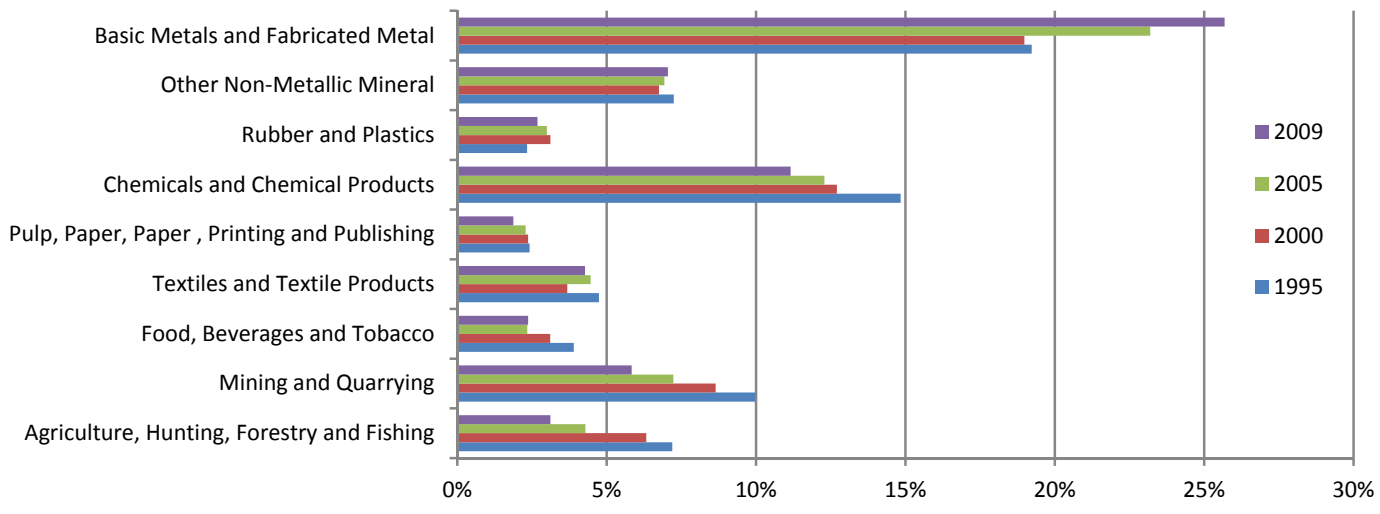

Figure 3. The main electricity consuming sectors.

\subsection{Economic Structure (ES)}

As shown in Figure 1, as a determinant of the $\mathrm{CO}_{2}$ emissions variation, the $\mathrm{ES}$ factor has failed to show a consistent trend. In six of the fourteen years studied, it showed a negative value. Specifically, this factor has contributed to an increase in $\mathrm{CO}_{2}$ emissions in China except in 1996, 2000, 2001, 2006, 2008 and 2009. Table A2 shows the ES weight factor for the 33 industrial sectors during 1995-2009. By comparing the decomposition value of each sector, we find the Electricity, Gas and Water Supply sector was the most influenced sector to the contribution of this determinant. Figure A1 represents the average proportions of Energy consumption by different industry sectors from 1995 to 2009 . It indicates that sector 17, the Electricity, Gas and Water Supply sector, accounts for around 34\% of the total energy consumption. Furthermore, according to the China Energy Statistical Yearbook [66], about 
$80 \%$ of China's electricity comes from coal-fired power production. This indicates that proportional consumption of coal in China directly determined carbon emissions.

From the perspective of the output of the 33 sectors, more powerful evidences illustrates that during 1995-2009, the economic structure has not been optimized as expected. Figure 4 represents the sector output ratio of total output in 33 sectors during 1995-2009. There were two important discoveries obtained from Figure 4.

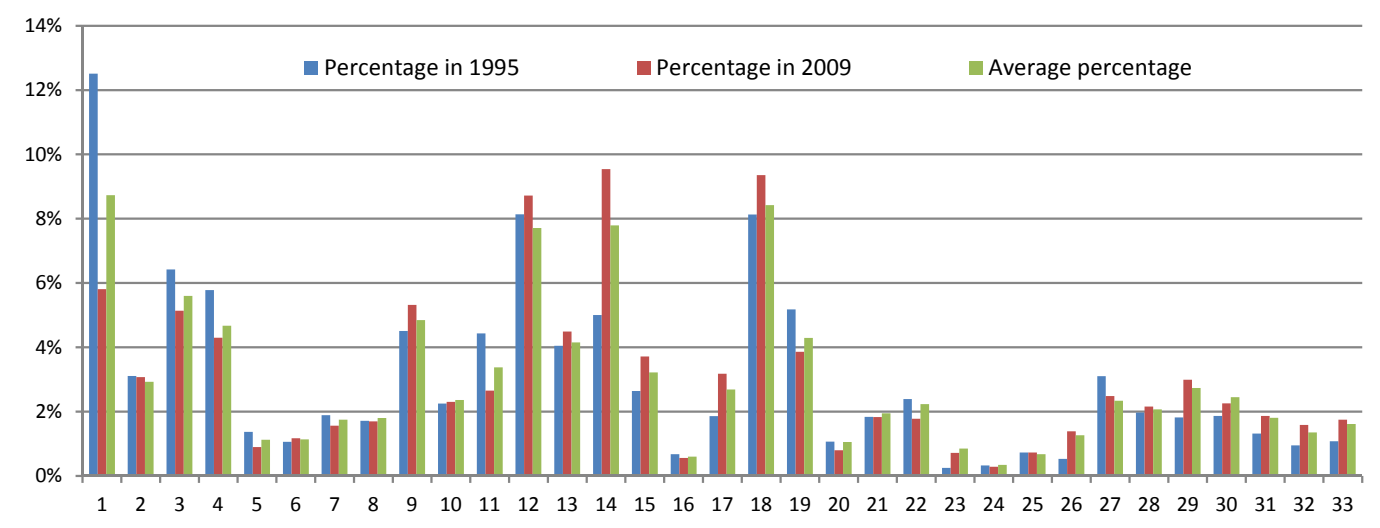

Figure 4. Percentage of output in 33 sectors.

On the one hand, by lateral contrast, it has been found the top seven output scales were Sector 1 (Agriculture, Hunting, Forestry and Fishing), 12 (Basic Metals and Fabricated Metal), 18 (Construction), 14 (Electrical and Optical Equipment), 3 (Food, Beverages and Tobacco), 9 (Chemicals and Chemical Products) and 4 (Textiles and Textile Products), in that order. As can be seen from this ranking, the proportion of secondary industry output in China is quite large. Specifically, the average percentage during 1995-2009 of Sector 1, which represents the primary industry, was 8.7\%. Moreover, the average percentage of Sector 12 and 18, representing secondary industry, was as high as 16.1\% between 1995 and 2009. In contrast, the average percentages of Sector 16 (Manufacturing, n.e.c.; Recycling), 23 (Water Transport), 24 (Air Transport), 25 (Other Supporting and Auxiliary Transport Activities; Activities of Travel Agencies), and 26 (Post and Telecommunications), which represent the tertiary industry with more efficient energy usage, were very low.

On the other hand, through longitudinal contrast, significant changes occurred in the proportion of the 33 sectors. In particular, the percentages of some sectors increased, such as sector 14 (Electrical and Optical Equipment), 18 (Construction), 9 (Chemicals and Chemical Products), 12 (Basic Metals and Fabricated Metal), and 15 (Transport Equipment). However, the percentages of the others decreased, which include Sector 1 (Agriculture, Hunting, Forestry and Fishing), 3 (Food, Beverages and Tobacco), 4 (Textiles and Textile Products), 11 (Other Non-Metallic Mineral), and 19 (Retail Trade, Except of Motor Vehicles and Motorcycles; Repair of Household Goods). Further analyses identify most sectors that with growing proportion accompanied higher energy intensity. In Sector 12, for example, the average of energy intensity during the period 1995-2009 was as high as $29.2 \mathrm{TJ} /$ millions dollars. On the contrary, the sectors with declining proportion often accompanied lower energy intensity. For instance, the average of energy intensity of sector 19 was $2.7 \mathrm{TJ} /$ millions dollars, less than one-tenth that of sector 12 .

Through horizontal and vertical comparison, we can conclude that the economic structure in China is irrational. This is specifically manifested in the following two aspects: the large and growing proportion of heavy industry, and relatively low levels and glacial growth of tertiary industry. This trend of economic structure means lower energy efficiency and more $\mathrm{CO}_{2}$ emissions. 


\subsection{The Carbon Intensity (CI) and Population (P) Factors}

Regarding the CI factor, it must be stressed that this factor captures the cleanliness of China's energy matrix. As Figure 1 shows, the CI does not follow a regular pattern from 1995 to 2009; and the overwhelming majority of years are negative which positively contributes to diminishing $\mathrm{CO}_{2}$ emissions. However, for 1998 and 2004, it is positive which indicates $\mathrm{CI}$ increased $\mathrm{CO}_{2}$ emissions. The underlying cause may be the sharp increase demand for coal in the Basic Metals and Fabricated Metal sector. Note that the values in 1997, 1999 and 2000, even though they were positive, CI actually reduced $\mathrm{CO}_{2}$ emissions, which was explained by the negative value of $\mathrm{CO}_{2}$ emissions variation. Therefore, in general, $\mathrm{CI}$ plays a role in reducing $\mathrm{CO}_{2}$ emissions in China, despite the effect is weak. To achieve a better understanding of this factor, a richer analysis based on Table S3 and Figure 5 may be conducted.

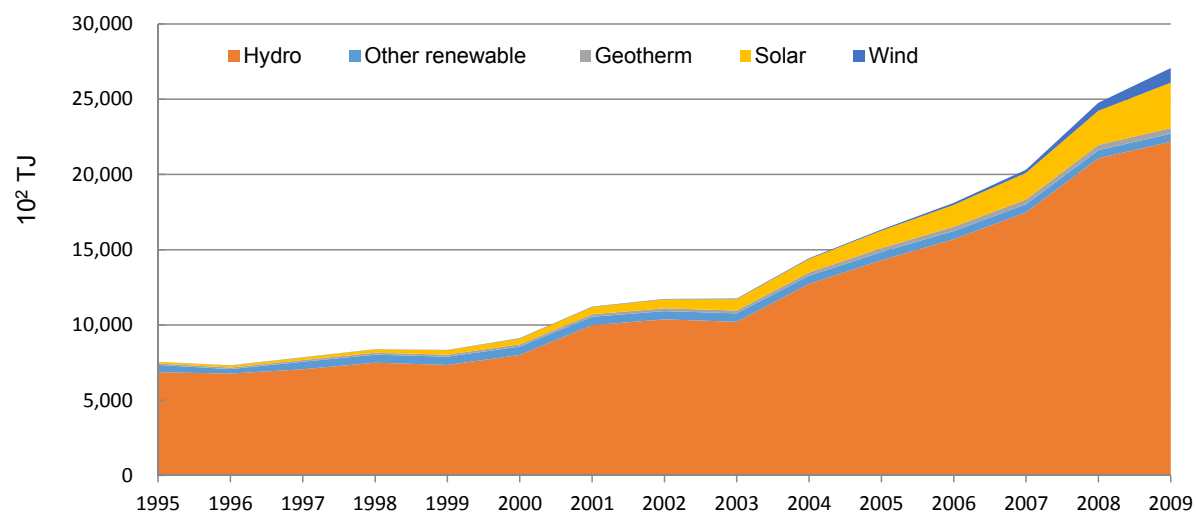

Figure 5. Gross renewable energy consumption in China during 1995-2009.

Table A3 represents the total primary energy consumption in China and Figure 5 shows the gross renewable energy use in China. An interesting discussion can result from examining these two. From Table A3, it can been seen, RES showed a weak upwards trend during the study period, in particular, the percentage of RES rose from $1.7 \%$ in 1995 to $2.4 \%$ in 2009. Meanwhile, the proportion of solid fuels used in total energy decreased from $61 \%$ in 1995 to $57 \%$ in 2009, even though its absolute value was increasing. Moreover, the ratio of electricity consumption has grown from $6.5 \%$ to $9.5 \%$ during the research period. During the sub-period of 1999-2003, the CI factor is negative, thus coinciding with years when there was less use of coal as a primary energy source, an increasing use of electricity and RES. In particular in 2001, China's energy mix is cleaner with the higher ratio of RES and gas, which partly replace coal and petroleum products.

As Figure 5 shows, the main contribution of RES is hydroelectric power, which accounts for $90.8 \%$ in 1995 and $81.9 \%$ in 2009. Compared with other countries in the developed world (USA, France, Spain) or developing world (Mexico, South Africa and India), China's hydropower production has risen sharply [67]. In addition, the ratio of solar, wind and nuclear increased. Since 1995, China paid more attention to the development of RES and launched a series of policies to promote the utilization of RES. In wind power, for example, the National Economic and Trade Committee, National Development and Reform Commission, and Ministry of Finance of China formulated and published some preferential policies for wind power generation in 1999, 2005 and 2008 [68,69]. In general, the energy mix in China became cleaner, which helps reduce total $\mathrm{CO}_{2}$ emissions.

The role of population in $\mathrm{CO}_{2}$ emissions has been researched extensively in the literature. As Figure 1 shows, demographic growth has contributed to increased $\mathrm{CO}_{2}$ emissions in China during the study period. Furthermore, from 2002 to 2008, the contribution rate of the population to $\mathrm{CO}_{2}$ emissions declines continuously, which coincides with the reduction of natural population growth rate. However, compared with the EA factor and ES factor, the effect of population on $\mathrm{CO}_{2}$ emission was obviously weak. These results are consistent with those of previous studies $[21,52]$. 


\section{Conclusions and Policy Implications}

The period of 1995-2009 witnessed the fast growth of China's economy, along with an increased use of fossil fuels and corresponding increase in $\mathrm{CO}_{2}$ emissions. From the perspective of 33 sectors, this paper investigated the factors influencing changes in $\mathrm{CO}_{2}$ emission and emphasized on the role of renewable energy system or RES. The main results of the study are as follows:

Economic activity played a significant role in increased $\mathrm{CO}_{2}$ emissions. Over the research period, $35.77 \%$ of the variation in $\mathrm{CO}_{2}$ emissions was caused by economic growth. However, the link between economic growth and $\mathrm{CO}_{2}$ emissions has changed from 2004. This means that since 2004, a green economic development model has gradually formed and economic growth is no longer directly linked to the cost of large energy consumption and high carbon emissions.

Economic structure was another contributor to increased $\mathrm{CO}_{2}$ emissions. Deeper analysis reveals that the sector of Electricity, Gas and Water Supply was the most influenced sector to the contribution of this determinant. This was followed by the sectors of Chemicals and Chemical Products, Basic Metals and Fabricated Metal and Other Non-Metallic Mineral, which were characterized by low energy efficiency. In general, because of the progress of industrialization and urbanization, the economic structure factor has not been optimized. In contrast, it shows a rising trend in the proportion of heavy industry.

Energy intensity and energy mix were the two key factors in reducing total $\mathrm{CO}_{2}$ emissions. The role of energy intensity is particularly prominent. In terms of sectors, the Electricity, Gas and Water Supply sector and the Basic Metals and Fabricated Metal sector are the two key economic sectors that influence the symbol of the EI effectively, followed by the sectors of Chemicals and Chemical Products, Other Non-Metallic Mineral and Mining and Quarrying. During the study period, the total energy intensity has greatly improved which inhibits an increase in $\mathrm{CO}_{2}$ emissions. With regard to the energy mix, the declining ratio of solid fuels along with the increased ratio of RES, particularly hydropower, makes the energy structure optimized. Thus, a cleaner of energy mix helps reduce total $\mathrm{CO}_{2}$ emissions.

In accordance with the results obtained, two types of energy policy recommendations are put forward over the forthcoming years:

First, special attention should be paid to the power sector because of its determinant role in the behavior of the EI factor for the entire group of 33 sectors. There are two measures to reduce the energy intensity of the power sector: one is to improve the energy efficiency in these main electricity consumers, such as the Basic Metals and Fabricated Metal sector, the Chemicals and Chemical Products sector, and the Mining and Quarrying sector. The other is the adoption of clean power, namely reducing the proportion of coal-based power production and, controlling the proportion of the hydropower production, while increasing the production capacity of nuclear power, wind power and solar power. The reasons for controlling the production capacity of hydropower are that hydropower has reached its limit and there is increasing concern for the protection of the environment. Therefore, policy makers should focus on the development of wind and solar power.

Second, the industrial structure needs to be conscientiously optimized. There are three main methods to achieve this goal. The first method is inhibiting the excessive growth of high-carbon industry and improving sector productivity, particularly in sectors with high-energy intensity, such as the Coke, Refined Petroleum and Nuclear Fuel sector. The second is to upgrade traditional manufacturing industries with advanced technologies and encourage the export of surplus production capacity with relative competitiveness. The last approach will vigorously develop strategic emerging industries and services through continual liberalization of the market.

Acknowledgments: The current work is supported by the Foundation of Director of Xinjiang Institute of Ecology and Geography, Chinese Academy of Sciences (Y173051001) and (Y035112001).

Author Contributions: Jie-fang Dong conceived and designed the experiments; Chun Deng performed the experiments; Xing-min Wang analyzed the data; Xiao-lei Zhang contributed reagents/materials/analysis tools; and Qiang Wang wrote the paper. All authors read and approved the final manuscript.

Conflicts of Interest: The authors declare no conflict of interest. 


\section{Appendix A}

Table A1. EI weight factor for the 33 industrial sectors. Souse: own production.

\begin{tabular}{|c|c|c|c|c|c|c|c|c|c|c|c|c|c|c|}
\hline EI & 1996 & 1997 & 1998 & 1999 & 2000 & 2001 & 2002 & 2003 & 2004 & 2005 & 2006 & 2007 & 2008 & 2009 \\
\hline $\begin{array}{l}\text { Agriculture, Hunting, } \\
\text { Forestry and Fishing }\end{array}$ & $-12,227.37$ & 150.86 & -337.19 & 3170.20 & $-17,252.72$ & -471.12 & 640.04 & 3839.87 & -5558.18 & 6887.61 & -2752.32 & $-29,615.31$ & $-44,826.03$ & -3752.80 \\
\hline Mining and Quarrying & -7758.92 & -8070.92 & $11,331.24$ & $-10,548.71$ & $-13,568.96$ & 7442.76 & 1979.59 & -5241.79 & $-26,518.50$ & $-19,294.30$ & $-21,542.21$ & $-15,742.84$ & -8208.88 & $-13,889.08$ \\
\hline Food, Beverages and Tobacco & $-22,152.86$ & $-12,108.94$ & 8836.78 & -9528.61 & -8058.58 & -939.56 & -1789.08 & -9083.76 & 1487.04 & -5083.52 & $-10,162.29$ & $-10,853.63$ & -4746.06 & -3180.46 \\
\hline Textiles and Textile Products & $-14,429.49$ & -1976.59 & 309.25 & -7908.64 & -3758.92 & -1078.24 & -78.23 & -729.32 & 6656.14 & -4551.74 & -6001.04 & -5766.96 & -8473.64 & -4082.88 \\
\hline Leather, Leather and Footwear & -1301.21 & -89.22 & 68.53 & -355.13 & -301.42 & -199.42 & -71.26 & 108.05 & 640.32 & -490.16 & -495.69 & -436.54 & -656.83 & -242.91 \\
\hline $\begin{array}{l}\text { Wood and Products } \\
\text { of Wood and Cork }\end{array}$ & -2778.19 & -654.21 & -55.36 & -893.19 & -959.58 & -270.64 & -307.71 & 200.26 & 739.95 & -717.13 & -1973.48 & -1970.95 & -728.30 & -291.43 \\
\hline $\begin{array}{c}\text { Pulp, Paper, Paper, } \\
\text { Printing and Publishing }\end{array}$ & $-11,465.07$ & -4454.56 & 1414.13 & -5047.93 & 493.89 & -1102.23 & 955.37 & -2278.86 & 306.27 & -6472.35 & -1352.07 & -8199.97 & -1906.03 & -1547.74 \\
\hline $\begin{array}{l}\text { Coke, Refined Petroleum } \\
\text { and Nuclear Fuel }\end{array}$ & -1190.60 & -1083.90 & 422.26 & -3260.90 & $-10,207.73$ & -5617.75 & -2926.13 & 5087.75 & $-14,289.96$ & -5674.05 & 5058.63 & $-15,729.60$ & $-22,887.97$ & 6407.24 \\
\hline Chemicals and Chemical Products & $-22,649.51$ & $-24,515.39$ & 9974.47 & $-35,655.93$ & $-12,234.88$ & $-11,067.21$ & -1658.79 & $-16,588.33$ & $-26,907.42$ & $-25,001.44$ & $-22,717.68$ & $-50,213.97$ & $-41,340.00$ & $-11,768.84$ \\
\hline Rubber and Plastics & -5177.78 & -6177.24 & -108.74 & -1567.83 & -2992.66 & -755.44 & -1154.83 & -860.18 & 1637.70 & -2312.89 & -4380.08 & -3939.83 & -2147.24 & -1018.65 \\
\hline Other Non-Metallic Mineral & $-64,578.43$ & $-49,566.98$ & $34,918.56$ & $-43,553.02$ & $-25,238.16$ & $-19,071.70$ & 6671.67 & $21,061.77$ & $95,681.70$ & $-71,947.65$ & $-63,735.92$ & $-115,586.5$ & $11,575.12$ & -8954.89 \\
\hline Basic Metals and Fabricated Metal & $-30,674.76$ & $-18,080.85$ & $-13,647.95$ & $-11,860.40$ & $-13,684.92$ & $-12,349.50$ & $19,203.62$ & $-15,297.53$ & $-43,478.61$ & $10,815.47$ & $-55,517.92$ & $-98,506.69$ & $-96,501.89$ & 757.31 \\
\hline Machinery, n.e.c. & -3228.95 & -7319.47 & -2476.18 & -6749.26 & -5623.96 & -1514.56 & -474.73 & -2507.32 & -410.57 & -2909.67 & -5134.16 & -5462.43 & -2497.56 & -443.99 \\
\hline Electrical and Optical Equipment & -1513.87 & -3093.86 & -1668.63 & -2385.86 & -2244.56 & -785.81 & -291.23 & -1255.38 & -172.72 & -737.35 & -2795.91 & -2197.47 & -1373.28 & -437.97 \\
\hline Transport Equipment & -1749.37 & -1826.03 & -1063.33 & -2737.10 & -1127.90 & -1004.63 & -2397.70 & -3456.76 & 2365.86 & -3874.16 & -1670.54 & -5337.91 & -1447.40 & 795.69 \\
\hline Manufacturing, n.e.c.; Recycling & -2867.51 & -2815.70 & 350.58 & -1174.64 & -1391.89 & -571.80 & -577.24 & -620.56 & 676.94 & -945.51 & -1540.53 & -1121.17 & -389.16 & -344.91 \\
\hline Electricity, Gas and Water Supply & $-13,831.05$ & $-228,299.80$ & $-82,822.08$ & $-106,059.59$ & $19,422.17$ & $-67,445.38$ & 2285.30 & $-129,944.87$ & $-57,4677.05$ & $-329,972.16$ & $349,051.65$ & $-663,625.23$ & $-610,560.93$ & $42,741.19$ \\
\hline Construction & -393.83 & 74.81 & -109.20 & -3048.57 & -654.49 & -1616.51 & 64.69 & -2039.74 & $13,867.91$ & -5794.37 & -5852.95 & $-10,061.86$ & $-20,397.28$ & -492.77 \\
\hline $\begin{array}{l}\text { Wholesale Trade and } \\
\text { Commission Trade, Except of } \\
\text { Motor Vehicles and Motorcycles }\end{array}$ & -215.86 & -2620.59 & -1081.90 & 2509.64 & -2190.51 & -226.79 & -184.55 & -3341.40 & -1349.17 & -1320.81 & -677.91 & -1702.72 & -351.77 & -4.08 \\
\hline $\begin{array}{l}\text { Retail Trade, Except of Motor } \\
\text { Vehicles and Motorcycles; } \\
\text { Repair of Household Goods }\end{array}$ & 32.08 & -601.52 & -375.12 & 458.53 & -491.35 & -201.03 & -10.77 & -647.79 & -156.27 & -3223.08 & -691.40 & 1330.12 & -827.84 & -237.68 \\
\hline Hotels and Restaurants & -645.49 & -1667.97 & -14.48 & 378.96 & -10.62 & -128.37 & -73.08 & -370.49 & 2034.61 & -424.99 & 424.14 & -1530.09 & -442.24 & 1735.95 \\
\hline Inland Transport & -7504.25 & 4889.38 & 6802.55 & -1873.57 & -4208.90 & -4223.41 & -1026.97 & 4879.47 & -5802.14 & -902.75 & -8122.03 & $-13,742.15$ & $-11,364.10$ & -4864.65 \\
\hline Water Transport & -3375.69 & 1300.50 & -9849.21 & -4514.47 & -2667.25 & -6373.36 & -4888.02 & 6321.10 & -6037.13 & -359.23 & -2003.87 & -1197.03 & $-17,348.72$ & 86.65 \\
\hline Air Transport & -3865.42 & 1802.76 & 6619.10 & -4598.35 & -6345.11 & 4719.53 & 1296.59 & 6410.04 & 112.61 & -8609.47 & -6377.31 & -1134.63 & $-11,216.48$ & $29,567.10$ \\
\hline $\begin{array}{l}\text { Other Supporting and } \\
\text { Auxiliary Transport Activities; } \\
\text { Activities of Travel Agencies }\end{array}$ & 305.48 & -208.13 & -301.68 & 659.18 & 1180.18 & 276.08 & 558.69 & 3064.34 & 1147.84 & -3741.23 & -885.37 & -5315.35 & -4950.65 & -1070.66 \\
\hline
\end{tabular}


Table A1. Cont.

\begin{tabular}{|c|c|c|c|c|c|c|c|c|c|c|c|c|c|c|}
\hline EI & 1996 & 1997 & 1998 & 1999 & 2000 & 2001 & 2002 & 2003 & 2004 & 2005 & 2006 & 2007 & 2008 & 2009 \\
\hline Post and Telecommunications & -2.74 & -114.36 & -192.12 & -73.43 & 176.28 & -434.10 & -300.12 & -270.90 & -144.75 & -429.40 & -287.36 & -809.21 & -491.80 & -113.16 \\
\hline Financial Intermediation & -625.27 & -990.83 & 177.19 & 432.57 & -110.97 & 3.80 & 6.90 & -144.29 & -35.15 & -314.59 & -225.44 & -666.46 & -436.78 & -84.57 \\
\hline Real Estate Activities & -1713.62 & -3605.97 & -445.79 & -50.17 & -518.68 & -224.11 & -135.47 & -120.73 & -313.65 & -1071.51 & -1006.68 & -1488.43 & -430.01 & -192.89 \\
\hline $\begin{array}{l}\text { Renting of M\&Eq and } \\
\text { Other Business Activities }\end{array}$ & -746.48 & -3157.79 & 396.01 & 1142.95 & -1385.07 & -227.71 & -195.92 & -1321.58 & 954.95 & -1774.87 & -1126.54 & -2883.47 & 165.32 & -293.99 \\
\hline $\begin{array}{l}\text { Public Admin and Defence; } \\
\text { Compulsory Social Security }\end{array}$ & -893.23 & -3086.03 & -1677.17 & 129.90 & -1708.33 & -807.86 & -682.41 & 146.76 & 1429.23 & -1013.61 & -232.90 & -2235.29 & 459.72 & -174.70 \\
\hline Education & -1199.37 & -6958.85 & -971.18 & -1100.80 & -1819.97 & -1317.18 & -910.96 & -1154.66 & -1470.95 & -1539.46 & -915.47 & -2559.12 & 237.81 & 82.13 \\
\hline Health and Social Work & -469.88 & -1877.46 & -313.12 & -398.98 & -700.57 & -358.59 & -416.73 & 52.03 & 229.38 & 65.13 & 487.71 & -1075.43 & 3203.39 & 472.48 \\
\hline $\begin{array}{l}\text { Other Community, Social } \\
\text { and Personal Services }\end{array}$ & -506.41 & -3987.32 & -4615.53 & -1499.77 & -3899.82 & -2502.29 & -1793.80 & -891.07 & 475.80 & -2139.44 & -1380.04 & -5955.99 & 79.70 & -857.98 \\
\hline $\begin{array}{l}\text { Total change of } \mathrm{CO}_{2} \\
\text { emissions from EI }\end{array}$ & $-241,394.93$ & $-390,792.20$ & $-40,505.32$ & $-257,562.93$ & $-124,085.93$ & $-130,444.14$ & $11,316.72$ & $-146,995.85$ & $-576,877.99$ & $-494,874.66$ & $123,465.01$ & $-1085,333.66$ & $-901,227.81$ & $24,302.04$ \\
\hline
\end{tabular}

Table A2. ES weight factor for the 33 industrial sectors. Souse: own production.

\begin{tabular}{|c|c|c|c|c|c|c|c|c|c|c|c|c|c|c|}
\hline ES & 1996 & 1997 & 1998 & 1999 & 2000 & 2001 & 2002 & 2003 & 2004 & 2005 & 2006 & 2007 & 2008 & 2009 \\
\hline $\begin{array}{l}\text { Agriculture, Hunting, } \\
\text { Forestry and Fishing }\end{array}$ & -301.77 & -6485.30 & -3665.93 & -6649.37 & -9004.14 & -3732.51 & -4002.46 & $-11,502.71$ & 2368.68 & $-18,103.87$ & $-17,430.68$ & -7450.74 & -614.72 & -2851.58 \\
\hline Mining and Quarrying & -5426.43 & -114.70 & -9618.47 & -746.82 & 8805.15 & $-10,110.05$ & -6900.93 & 4568.46 & $29,226.54$ & 3762.19 & -1207.14 & -6177.12 & -690.46 & -6104.85 \\
\hline Food, Beverages and Tobacco & 5042.89 & 130.51 & -4934.50 & -4103.27 & -4039.45 & -2161.97 & -2073.06 & 684.93 & -3183.31 & 1793.40 & 2472.33 & 605.52 & -253.45 & -2222.47 \\
\hline Textiles and Textile Products & -3282.18 & -4696.14 & -348.20 & -245.53 & 170.65 & 76.33 & -769.22 & -334.36 & -3751.98 & 1224.54 & 2220.79 & -1528.28 & -192.47 & -1587.45 \\
\hline Leather, Leather and Footwear & 252.39 & -199.81 & -133.31 & -223.92 & -117.01 & 25.39 & -79.51 & -69.87 & -609.40 & -25.76 & 138.76 & -165.75 & -13.87 & -113.24 \\
\hline $\begin{array}{l}\text { Wood and Products } \\
\text { of Wood and Cork }\end{array}$ & 463.88 & 213.07 & -269.30 & 10.34 & 62.45 & 216.60 & -209.17 & -167.36 & -519.30 & 245.96 & 1035.37 & 215.31 & -42.47 & -374.09 \\
\hline $\begin{array}{c}\text { Pulp, Paper, Paper, } \\
\text { Printing and Publishing }\end{array}$ & 2131.10 & -767.70 & -627.61 & -1197.69 & -1436.97 & -393.84 & -1287.23 & -37.84 & 2040.33 & 2045.35 & -4244.52 & -788.65 & -175.02 & -1617.92 \\
\hline $\begin{array}{l}\text { Coke, Refined Petroleum } \\
\text { and Nuclear Fuel }\end{array}$ & -4976.17 & 853.28 & -5764.51 & 4171.87 & $10,680.14$ & 2950.28 & 3464.15 & -7046.80 & $13,563.50$ & -1817.28 & $-19,193.24$ & 893.66 & -352.60 & -2987.54 \\
\hline Chemicals and Chemical Products & $11,364.18$ & -6438.75 & $-13,380.01$ & 5761.45 & 3796.63 & -4850.13 & 824.67 & $16,358.78$ & 1299.35 & 7930.59 & 4179.65 & $12,775.61$ & -1023.90 & -8582.97 \\
\hline Rubber and Plastics & 2690.82 & 808.38 & -147.15 & -1046.17 & -472.59 & -135.81 & -476.83 & 16.59 & -1190.83 & 955.39 & 1287.42 & 78.38 & -86.40 & -750.02 \\
\hline Other Non-Metallic Mineral & $11,575.64$ & 1069.86 & $-30,897.18$ & $-24,563.30$ & $-24,637.99$ & $-22,607.65$ & $-29,904.84$ & $-14,920.80$ & $-20,035.99$ & $10,792.82$ & $-25,243.46$ & -7375.76 & -2531.40 & $-22,203.24$ \\
\hline Basic Metals and Fabricated Metal & -5986.53 & -702.89 & $-19,667.34$ & $-17,180.56$ & $-10,155.73$ & -8304.74 & $-16,396.08$ & $41,342.76$ & $32,329.76$ & $11,892.38$ & $52,410.21$ & $19,872.02$ & -2221.46 & $-18,696.18$ \\
\hline Machinery, n.e.c. & -2450.72 & -982.41 & -212.63 & 484.81 & 539.19 & 816.54 & 729.31 & 1105.75 & -239.52 & 667.40 & 1419.55 & 499.66 & -133.09 & -1188.06 \\
\hline Electrical and Optical Equipment & -62.91 & 1273.34 & 1358.06 & 851.53 & 1332.01 & 134.90 & 645.82 & 660.54 & 510.16 & 628.37 & 2038.50 & -499.64 & -65.54 & -580.08 \\
\hline
\end{tabular}


Table A2. Cont.

\begin{tabular}{|c|c|c|c|c|c|c|c|c|c|c|c|c|c|c|}
\hline ES & 1996 & 1997 & 1998 & 1999 & 2000 & 2001 & 2002 & 2003 & 2004 & 2005 & 2006 & 2007 & 2008 & 2009 \\
\hline Transport Equipment & -72.89 & 17.58 & 407.24 & 142.82 & -267.15 & 993.95 & 1734.75 & 1871.25 & -1396.81 & 796.97 & -664.89 & 2106.97 & -86.90 & -778.72 \\
\hline Manufacturing, n.e.c.; Recycling & -227.64 & -639.26 & -279.73 & 413.29 & 269.98 & 332.60 & 166.86 & -537.98 & -1705.26 & -38.76 & 1266.56 & -196.36 & -20.68 & -179.43 \\
\hline Electricity, Gas and Water Supply & $-70,940.99$ & $171,796.25$ & $75,464.92$ & $89,733.53$ & $-69,840.84$ & $30,792.38$ & $47,045.04$ & $179,612.80$ & $604,711.29$ & $211,714.50$ & $-546,102.86$ & $196,837.26$ & $-12,042.30$ & $-100,214.69$ \\
\hline Construction & 117.55 & -778.62 & 1081.88 & 393.23 & 29.50 & 249.86 & 730.79 & -294.78 & -1360.97 & -333.40 & -814.75 & -1025.22 & 2228.71 & 7157.06 \\
\hline $\begin{array}{c}\text { Wholesale Trade and } \\
\text { Commission Trade, Except of } \\
\text { Motor Vehicles and Motorcycles }\end{array}$ & -472.77 & -123.02 & 191.48 & 119.22 & -497.86 & -8.74 & -213.28 & -889.36 & -994.56 & -3092.92 & -272.64 & 1682.82 & 370.22 & 262.87 \\
\hline $\begin{array}{l}\text { Retail Trade, Except of } \\
\text { Motor Vehicles and Motorcycles; } \\
\text { Repair of Household Goods }\end{array}$ & -152.01 & -41.76 & 69.00 & 41.80 & -176.26 & -3.25 & -80.34 & -387.81 & -542.31 & 4816.50 & -352.64 & -5627.57 & 358.85 & 236.92 \\
\hline Hotels and Restaurants & -436.43 & 228.18 & 381.55 & 158.49 & 23.03 & 115.04 & 247.41 & -51.39 & -99.85 & -361.35 & -570.93 & -884.73 & 126.27 & 91.89 \\
\hline Inland Transport & -917.78 & -1133.17 & 2215.40 & 1928.60 & 3596.51 & -269.98 & -1389.75 & -7135.58 & -1539.80 & -5413.46 & -3977.55 & -3263.26 & -5196.29 & -2654.79 \\
\hline Water Transport & 1385.91 & 1374.50 & $15,011.62$ & $12,445.21$ & $13,637.45$ & $10,494.14$ & 8550.75 & $-11,827.75$ & -6156.64 & -6560.62 & -7230.07 & $-15,731.01$ & -5143.80 & -2624.90 \\
\hline Air Transport & -14.07 & -67.68 & 1274.74 & 1288.28 & 1715.06 & 429.09 & 51.07 & -2504.95 & -172.29 & -7697.31 & 628.44 & -572.30 & -2537.27 & -1626.77 \\
\hline $\begin{array}{l}\text { Other Supporting and } \\
\text { Auxiliary Transport Activities; } \\
\text { Activities of Travel Agencies }\end{array}$ & 185.04 & 175.49 & -206.92 & -360.50 & -449.71 & -1122.62 & -1523.64 & 1300.32 & 2698.61 & 4641.53 & -1399.29 & 3328.89 & -1621.89 & -819.82 \\
\hline Post and Telecommunications & 164.23 & 283.45 & 308.03 & 322.74 & 388.74 & 513.70 & 435.51 & 26.06 & 34.87 & -154.87 & -305.10 & -415.71 & 36.12 & 176.77 \\
\hline Financial Intermediation & -194.97 & -58.13 & -104.91 & -89.59 & -107.44 & -99.80 & -97.74 & -207.14 & -278.87 & -181.25 & 175.00 & 473.57 & 52.81 & 333.57 \\
\hline Real Estate Activities & -492.36 & 23.44 & 470.03 & 73.16 & 97.68 & 154.95 & 179.39 & -208.98 & -323.87 & -195.97 & -114.15 & 118.40 & -359.21 & 630.02 \\
\hline $\begin{array}{l}\text { Renting of M\&Eq and } \\
\text { Other Business Activities }\end{array}$ & 613.26 & 1247.91 & 656.87 & 559.78 & 354.67 & 522.65 & 264.92 & -36.31 & -83.52 & 116.78 & -376.44 & 63.67 & 139.81 & 770.79 \\
\hline $\begin{array}{l}\text { Public Admin and Defence; } \\
\text { Compulsory Social Security }\end{array}$ & 386.53 & 1230.56 & 802.67 & 603.28 & 378.44 & 514.41 & 272.12 & -427.82 & -564.40 & -430.22 & -959.53 & -1668.19 & 135.85 & 768.45 \\
\hline $\begin{array}{l}\text { Education } \\
\end{array}$ & 1182.95 & 2356.25 & 993.67 & 666.59 & 309.22 & 499.36 & 148.97 & -325.90 & -369.69 & 40.01 & -341.20 & -130.85 & 98.16 & 569.73 \\
\hline Health and Social Work & 432.71 & 812.88 & 217.25 & 88.89 & -34.81 & 8.24 & -108.80 & 230.84 & 260.37 & 378.22 & 188.14 & 106.34 & 102.37 & 657.39 \\
\hline $\begin{array}{l}\text { Other Community, Social } \\
\text { and Personal Services }\end{array}$ & 590.04 & 2275.59 & 2104.37 & 1645.71 & 1190.17 & 1477.51 & 1016.06 & -610.20 & -737.94 & -303.45 & -1135.62 & 609.93 & 213.00 & 1161.24 \\
\hline
\end{tabular}


Table A3. Gross inland consumption $\left(10^{4} \mathrm{TJ}\right)$. Souse: own production based on WIOD.

\begin{tabular}{|c|c|c|c|c|c|c|c|c|c|c|c|c|c|c|c|}
\hline Fuel Type & 1995 & 1996 & 1997 & 1998 & 1999 & 2000 & 2001 & 2002 & 2003 & 2004 & 2005 & 2006 & 2007 & 2008 & 2009 \\
\hline Solid fuels & $279,204.6$ & $285,996.4$ & $282,023.1$ & $287,344.4$ & $271,638.5$ & $267,573.3$ & $272,000.3$ & $297,963.4$ & $353,855.0$ & $421,589.2$ & $477,183.6$ & $528,646.7$ & $575,569.2$ & $615,027.3$ & $651,588.6$ \\
\hline coal & $263,478.4$ & $269,873.5$ & $266,347.5$ & $274,164.8$ & $258,838.0$ & $254,746.6$ & $257,605.2$ & $281,285.5$ & $335,645.2$ & $400,806.8$ & $451,543.5$ & $502,046.6$ & $544,976.0$ & $589,221.8$ & $621,389.9$ \\
\hline coke & $15,726.2$ & $16,122.9$ & $15,675.6$ & $13,179.6$ & $12,800.6$ & $12,826.7$ & $14,395.1$ & $16,677.9$ & $18,209.7$ & $20,782.4$ & $25,640.1$ & $26,600.2$ & $30,593.2$ & $25,805.5$ & $30,198.7$ \\
\hline Total petroleum products & $117,375.3$ & $125,083.1$ & $136,981.6$ & $141,323.5$ & $150,373.7$ & $161,868.4$ & $165,706.4$ & $177,021.8$ & $195,546.5$ & $225,656.2$ & $232,064.0$ & $246,808.1$ & $257,893.7$ & $266,576.1$ & $287,164.0$ \\
\hline crude oil & $61,669.1$ & $65,754.1$ & $72,001.7$ & $72,097.1$ & $78,637.9$ & $88,128.2$ & $88,612.3$ & $93,660.3$ & $103,693.7$ & $119,846.5$ & $125,426.3$ & $134,286.5$ & $141,772.6$ & $147,915.2$ & $158,981.4$ \\
\hline diesel & 1963.7 & 1991.7 & 2176.0 & 3460.1 & 4213.4 & 8614.0 & 8952.1 & 9543.9 & $10,559.0$ & $13,281.3$ & $15,606.1$ & $17,621.3$ & $19,266.1$ & $20,686.8$ & $21,439.3$ \\
\hline gasoline & 5949.9 & 6643.5 & 6800.9 & 6321.3 & 6012.8 & 4460.8 & 4418.8 & 4377.4 & 5066.3 & 5095.1 & 4498.8 & 4496.2 & 4294.4 & 4966.0 & 4804.4 \\
\hline fuel & $33,799.6$ & $34,472.0$ & $35,746.6$ & $38,732.9$ & $41,759.2$ & $38,701.3$ & $41,573.4$ & $44,532.7$ & $49,005.7$ & $55,053.5$ & $52,927.0$ & $54,403.2$ & $54,439.2$ & $55,164.3$ & $57,717.8$ \\
\hline other petroleum & $13,993.0$ & $16,221.8$ & $20,256.4$ & $20,712.1$ & $19,750.5$ & $21,964.1$ & $22,149.8$ & $24,907.5$ & $27,221.8$ & $32,379.9$ & $33,605.8$ & $36,001.0$ & $38,121.4$ & $37,843.9$ & $44,221.1$ \\
\hline Gas & $10,208.7$ & $10,663.8$ & $11,075.8$ & $11,122.5$ & $11,401.0$ & $12,490.2$ & $13,500.3$ & $14,235.9$ & $16,402.4$ & $19,365.9$ & $24,037.9$ & $27,509.8$ & $31,958.1$ & $35,403.5$ & $37,791.1$ \\
\hline natural gas & 5437.2 & 5474.4 & 6008.7 & 6052.3 & 6464.7 & 7217.5 & 7915.3 & 8383.9 & 9826.7 & $11,269.8$ & $13,087.7$ & $15,422.9$ & $19,143.3$ & $21,820.9$ & $24,264.3$ \\
\hline other gas & 4771.5 & 5189.4 & 5067.1 & 5070.2 & 4936.3 & 5272.7 & 5585.0 & 5852.0 & 6575.6 & 8096.1 & $10,950.2$ & $12,086.9$ & $12,814.8$ & $13,582.6$ & $13,526.8$ \\
\hline Electricity & $29,791.8$ & $31,912.1$ & $33,252.1$ & $34,127.3$ & $35,889.9$ & $39,135.7$ & $42,374.2$ & $47,422.3$ & $55,932.2$ & $65,154.4$ & $73,537.5$ & $84,636.1$ & $97,484.9$ & $101,341.8$ & $108,602.1$ \\
\hline Heat production & 9298.1 & 9644.0 & 9943.7 & $10,726.4$ & $11,266.0$ & $12,111.4$ & $12,800.9$ & $13,554.1$ & $14,157.6$ & $14,889.1$ & $17,447.9$ & $18,684.5$ & $19,770.0$ & $19,178.0$ & $19,653.0$ \\
\hline Renewable energies & 7553.3 & 7315.4 & 7852.8 & 8395.4 & 8345.7 & 9126.4 & $11,219.4$ & $11,735.4$ & $11,748.9$ & $14,436.5$ & $16,334.5$ & $18,112.0$ & $20,313.1$ & $24,761.3$ & $27,070.3$ \\
\hline other renewable & 485.9 & 298.1 & 492.8 & 539.2 & 548.4 & 552.2 & 556.1 & 554.3 & 552.5 & 550.7 & 548.8 & 546.6 & 544.7 & 537.2 & 536.2 \\
\hline hydro & 6862.0 & 6768.0 & 7056.7 & 7489.3 & 7338.4 & 8008.3 & 9989.3 & $10,368.9$ & $10,214.4$ & $12,729.9$ & $14,295.2$ & $15,691.1$ & $17,472.6$ & $21,070.5$ & $22,167.0$ \\
\hline geothermal & 90.5 & 103.1 & 115.7 & 128.3 & 140.9 & 153.5 & 166.8 & 180.2 & 193.5 & 206.8 & 261.5 & 292.0 & 314.9 & 351.5 & 381.2 \\
\hline solar & 112.6 & 142.6 & 180.1 & 225.2 & 300.2 & 390.2 & 480.2 & 600.6 & 751.2 & 901.2 & 1156.0 & 1443.1 & 1775.3 & 2269.2 & 3017.3 \\
\hline wind & 2.3 & 3.5 & 7.4 & 13.3 & 17.8 & 22.1 & 27.0 & 31.4 & 37.4 & 48.0 & 73.0 & 139.3 & 205.6 & 532.9 & 968.6 \\
\hline nuclear & 1400.2 & 1564.5 & 1573.2 & 1538.5 & 1631.1 & 1826.2 & 1906.4 & 2741.6 & 4729.1 & 5506.7 & 5792.5 & 5983.9 & 6779.0 & 7462.5 & 7652.4 \\
\hline Total consumption & $454,832.0$ & $472,179.2$ & $482,702.4$ & $494,578.1$ & $490,545.8$ & $504,131.6$ & $519,507.9$ & $564,674.5$ & $652,371.6$ & $766,598.0$ & $846,397.9$ & $930,381.2$ & $1,009,768.0$ & $1,069,750.5$ & $1,139,521.3$ \\
\hline
\end{tabular}




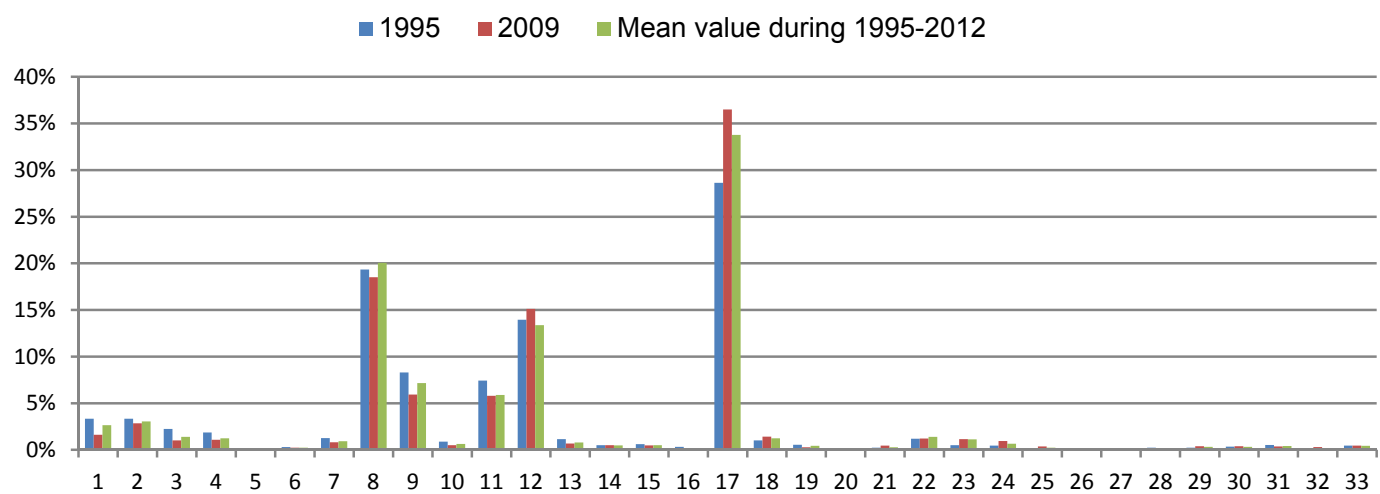

Figure A1. Percentage of energy consumption in 33 sectors.

\section{References}

1. Lin, B.Q.; Moubarak, M.; Ouyang, X.L. Carbon dioxide emissions and growth of the manufacturing sector: Evidence for China. Energy 2014, 76, 830-837. [CrossRef]

2. Tunç, G.İ.; Türüt-Aşık, S.; Akbostancı, E. A decomposition analysis of $\mathrm{CO}_{2}$ emissions from energy use: Turkish case. Energy Policy 2009, 37, 4689-4699. [CrossRef]

3. Ozturk, I.; Acaravci, A. $\mathrm{CO}_{2}$ emissions, energy consumption and economic growth in Turkey. Renew. Sust. Energ. Rev. 2010, 14, 3220-3225. [CrossRef]

4. Zhang, X.P.; Cheng, X.M. Energy consumption, carbon emissions, and economic growth in China. Ecol. Econ. 2009, 68, 2706-2712. [CrossRef]

5. Kang, J.D.; Zhao, T.; Liu, N.; Zhang, X.; Xu, X.S.; Lin, T. A multi-sectoral decomposition analysis of city-level greenhouse gas emissions: Case study of Tianjin, China. Energy 2014, 68, 562-571. [CrossRef]

6. Govindaraju, V.G.R.C.; Tang, C.F. The dynamic links between $\mathrm{CO}_{2}$ emissions, economic growth and coal consumption in China and India. Appl. Energy 2013, 102, 310-318. [CrossRef]

7. Yu, S.W.; Zhang, J.J.; Zheng, S.H.; Sun, H. Provincial carbon intensity abatement potential estimation in China: A PSO-GA-optimized multi-factor environmental learning curve method. Energy Policy 2015, 77, 46-55. [CrossRef]

8. Shahbaz, M.; Tiwari, A.K.; Nasir, M. The effects of financial development, economic growth, coal consumption and trade openness on $\mathrm{CO}_{2}$ emissions in South Africa. Energy Policy 2013, 61, 1452-1459. [CrossRef]

9. $\mathrm{Xu}, \mathrm{B}$; Lin, B.Q. How industrialization and urbanization process impacts on $\mathrm{CO}_{2}$ emissions in China: Evidence from nonparametric additive regression models. Energ. Econ. 2015, 48, 188-202. [CrossRef]

10. Al-mulali, U.; Fereidouni, H.G.; Lee, J.Y.M.; Che, N.B.C.S. Exploring the relationship between urbanization, energy consumption, and $\mathrm{CO}_{2}$ emission in MENA countries. Renew. Sust. Energ. Rev. 2013, 23, 107-112. [CrossRef]

11. Testa, R.; Foderà, M.; Trapani, A.M.D.; Tudisca, S.; Sgroi, F. Giant reed as energy crop for Southern Italy: An economic feasibility study. Renew. Sust. Energ. Rev. 2016, 58, 558-564. [CrossRef]

12. Poumanyvong, P.; Kaneko, S. Does urbanization lead to less energy use and lower $\mathrm{CO}_{2}$ emissions? A cross-country analysis. Ecol. Econ. 2010, 70, 434-444. [CrossRef]

13. Zhang, C.G.; Jiang, N. Panel estimation for transport sector $\mathrm{CO}_{2}$ emissions and its affecting factors: A regional analysis in China. Energy Policy 2013, 63, 918-926. [CrossRef]

14. Aydin, G. The Development and Validation of Regression Models to Predict Energy-related $\mathrm{CO}_{2}$ Emissions in Turkey. Energy Source Part B 2015, 10, 176-182. [CrossRef]

15. Grossman, G.M.; Krueger, A.B. Environmental Impacts of a North American Free Trade Agreement (November 1991). NBER Working Paper No. w3914. Available online: http://ssrn.com/abstract=232073 (accessed on 28 January 2016).

16. Zhang, M.; $\mathrm{Mu}$, H.L.; Ning, Y.D.; Song, Y.C. Decomposition of energy-related $\mathrm{CO}_{2}$ emission over 1991-2006 in China. Ecol. Econ. 2009, 68, 2122-2128. [CrossRef] 
17. Su, Y.; Chen, X.; Li, Y.; Liao, J.; Ye, Y.; Zhang, H.; Huang, N.; Kuang, Y. China's 19-year city-level carbon emissions of energy consumptions, driving forces and regionalized mitigation guidelines. Renew. Sust. Energ. Rev. 2014, 35, 231-243.

18. Ang, B.W.; Zhang, F.Q. A survey of index decomposition analysis in energy and environmental studies. Energy 2000, 25, 1149-1176.

19. Hasanbeigi, A.; Price, L.; Fino-Chen, C.; Lu, H.; Ke, J. Retrospective and prospective decomposition analysis of Chinese manufacturing energy use and policy implications. Energy Policy 2013, 63, 562-574.

20. Wang, S.; Fang, C.; Guan, X.; Pang, B.; Ma, H. Urbanisation, energy consumption, and carbon dioxide emissions in China: A panel data analysis of China's provinces. Appl. Energy 2014, 136, 738-749.

21. Xu, S.C.; He, Z.X.; Long, R.Y. Factors that influence carbon emissions due to energy consumption in China: Decomposition analysis using LMDI. Appl. Energy 2014, 127, 182-193.

22. Lin, B.Q.; Mohamed, M. Renewable energy consumption-Economic growth nexus for China. Renew. Sust. Energ. Rev. 2014, 40, 111-117.

23. Xie, S.C. The driving forces of China's energy use from 1992 to 2010: An empirical study of input-output and structural decomposition analysis. Energy Policy 2014, 73, 401-415.

24. Wang, C.; Chen, J.; Zou, J. Decomposition of energy-related $\mathrm{CO}_{2}$ emission in China: 1957-2000. Energy 2005, 30, 73-83.

25. Zhang, M.; Li, H.; Zhou, M.; Mu, H. Decomposition analysis of energy consumption in Chinese transportation sector. Appl. Energy 2011, 88, 2279-2285.

26. Freitas, L.C.D.; Kaneko, S. Decomposition of $\mathrm{CO}_{2}$ emissions change from energy consumption in Brazil: Challenges and policy implications. Energy Policy 2011, 39, 1495-1504.

27. Xu, J.H.; Fleiter, T.; Eichhammer, W.; Fan, Y. Energy consumption and $\mathrm{CO}_{2}$ emissions in China's cement industry: A perspective from LMDI decomposition analysis. Energy Policy 2012, 50, 821-832.

28. Komal, R.; Abbas, F.; Komal, R.; Abbas, F. Linking financial development, economic growth and energy consumption in Pakistan. Renew. Sust. Energ. Rev. 2015, 44, 211-220.

29. Zhang, Y.J.; Da, Y.B. The decomposition of energy-related carbon emission and its decoupling with economic growth in China. Renew. Sust. Energ. Rev. 2015, 41, 1255-1266.

30. Granger, C.W.J. Some recent development in a concept of causality. J. Econom. 1988, 39, 199-211.

31. Inglesi-Lotz, R.; Pouris, A. Energy efficiency in South Africa: A decomposition exercise. Energy 2012, 42, 113-120.

32. Ang, B.W. The LMDI approach to decomposition analysis: A practical guide. Energy Policy 2005, 33, 867-871.

33. Ang, B.W. Decomposition analysis for policymaking in energy: Which is the preferred method? Energy Policy 2004, 32, 1131-1139.

34. Paul, S.; Bhattacharya, R.N. $\mathrm{CO}_{2}$ emission from energy use in India: A decomposition analysis. Energy Policy 2004, 32, 585-593. [CrossRef]

35. Kumbaroğlu, G. A sectoral decomposition analysis of Turkish $\mathrm{CO}_{2}$ emissions over 1990-2007. Energy 2011, 36, 2419-2433. [CrossRef]

36. Begum, R.A.; Sohag, K.; Abdullah, S.M.S.; Jaafar, M. $\mathrm{CO}_{2}$ emissions, energy consumption, economic and population growth in Malaysia. Renew. Sust. Energ. Rev. 2015, 41, 594-601. [CrossRef]

37. Oh, I.; Wehrmeyer, W.; Mulugetta, Y. Decomposition analysis and mitigation strategies of $\mathrm{CO}_{2}$ emissions from energy consumption in South Korea. Energy Policy 2010, 38, 364-377. [CrossRef]

38. Robaina Alves, M.; Moutinho, V. Decomposition analysis and Innovative Accounting Approach for energy-related $\mathrm{CO}_{2}$ emissions intensity over 1996-2009 in Portugal. Energy 2013, 57, 775-787.

39. Brizga, J.; Feng, K.; Hubacek, K. Drivers of $\mathrm{CO}_{2}$ emissions in the former Soviet Union: A country level IPAT analysis from 1990 to 2010. Energy 2013, 59, 743-753. [CrossRef]

40. Jiang, Z.; Lin, B.Q. China's energy demand and its characteristics in the industrialization and urbanization process. Energy Policy 2012, 49, 608-615. [CrossRef]

41. Moutinho, V.; Moreira, A.C.; Silva, P.M. The driving forces of change in energy-related $\mathrm{CO}_{2}$ emissions in Eastern, Western, Northern and Southern Europe: The LMDI approach to decomposition analysis. Renew. Sust. Energ. Rev. 2015, 50, 1485-1499. [CrossRef]

42. Hatzigeorgiou, E.; Polatidis, H.; Haralambopoulos, D. Energy $\mathrm{CO}_{2}$ Emissions for 1990-2020: A Decomposition Analysis for EU25 and Greece. Energy Source Part A 2010, 32, 1908-1917. [CrossRef] 
43. Chong, C.H.; Ma, L.; Li, Z.; Ni, W.; Song, S. Logarithmic mean Divisia index (LMDI) decomposition of coal consumption in China based on the energy allocation diagram of coal flows. Energy 2015, 85, 366-378. [CrossRef]

44. Sheinbaum, C.; Ruíz, B.J.; Ozawa, L. Energy consumption and related $\mathrm{CO}_{2}$ emissions in five Latin American countries: Changes from 1990 to 2006 and perspectives. Energy 2011, 36, 3629-3638. [CrossRef]

45. Sheinbaum-Pardo, C.; Mora-Pérez, S.; Robles-Morales, G. Decomposition of energy consumption and $\mathrm{CO}_{2}$ emissions in Mexican manufacturing industries: Trends between 1990 and 2008. Energy. Sustain. Dev. 2012, 16,57-67. [CrossRef]

46. Andreoni, V.; Galmarini, S. Decoupling economic growth from carbon dioxide emissions: A decomposition analysis of Italian energy consumption. Energy 2012, 44, 682-691. [CrossRef]

47. González, P.F.; Moreno, B. Analyzing driving forces behind changes in energy vulnerability of Spanish electricity generation through a Divisia index-based method. Energ. Convers. Mang. 2015, 92, 459-468. [CrossRef]

48. Mahony, T.O.; Zhou, P.; Sweeney, J. The driving forces of change in energy-related $\mathrm{CO}_{2}$ emissions in Ireland: A multi-sectoral decomposition from 1990 to 2007. Energy Policy 2012, 44, 256-267. [CrossRef]

49. Mahony, T.O.; Zhou, P.; Sweeney, J. Integrated scenarios of energy-related $\mathrm{CO}_{2}$ emissions in Ireland: A multi-sectoral analysis to 2020. Ecol. Econ. 2013, 93, 358-397. [CrossRef]

50. Yuan, L.B. A Structural Decomposition Analysis of $\mathrm{CO}_{2}$ Emission in China. Adv. Mater. Res. 2011, 361-363, 1756-1760. [CrossRef]

51. Song, M.; Wang, S.; Yu, H.; Yang, L.; Wu, J. To reduce energy consumption and to maintain rapid economic growth: Analysis of the condition in China based on expended IPAT model. Renew. Sust. Energ. Rev. 2011, 15, 5129-5134. [CrossRef]

52. Guo, B.; Geng, Y.; Franke, B.; Han, H.; Liu, Y.; Chiu, A. Uncovering China's transport $\mathrm{CO}_{2}$ emission patterns at the regional level. Energy Policy 2014, 74, 134-146. [CrossRef]

53. Hazuki, I. The effect of ICT development on economic growth and energy consumption in Japan. Telemat. Inform. 2015, 32, 79-88.

54. Liu, N.; Ma, Z.; Kang, J. Changes in carbon intensity in China's industrial sector: Decomposition and attribution analysis. Energy Policy 2015, 87, 28-38. [CrossRef]

55. Fan, J.L.; Liao, H.; Liang, Q.M.; Tatano, H.; Liu, C.F.; Wei, Y.M. Residential carbon emission evolutions in urban-rural divided China: An end-use and behavior analysis. Appl. Energy 2013, 101, 323-332. [CrossRef]

56. Ouyang, X.; Lin, B.Q. An analysis of the driving forces of energy-related carbon dioxide emissions in China's industrial sector. Renew. Sust. Energ. Rev. 2015, 45, 838-849. [CrossRef]

57. Muhammad, S.; Sahbi, F.; Ilhan, O. Do coal consumption and industrial development increase environmental degradation in China and India? Environ. Sci. Pollut. Res. 2015, 22, 3895-3907.

58. Dietz, T.; Rosa, E.A. Effects of population and affluence on $\mathrm{CO}_{2}$ emissions. Proc. Natl. Acad. Sci. USA 1997, 94, 175-179. [CrossRef] [PubMed]

59. Hassan, H.; Katircioğlu, S.T.; Saeidpour, L. Economic growth, $\mathrm{CO}_{2}$ emissions, and energy consumption in the five ASEAN countries. Int. J. Electr. Power Energy Syst. 2015, 64, 785-791.

60. Liu, Z.; Liang, S.; Geng, Y.; Xue, B.; Xi, F.; Pan, Y.; Zhang, T.; Fujita, T. Features, trajectories and driving forces for energy-related GHG emissions from Chinese mega cites: The case of Beijing, Tianjin, Shanghai and Chongqing. Energy 2012, 37, 245-254. [CrossRef]

61. Hubacek, K.; Feng, K.; Chen, B. Changing Lifestyles towards a Low Carbon Economy: An IPAT Analysis for China. Energies 2011, 5, 22-31. [CrossRef]

62. Chen, L.; Yang, Z.; Chen, B. Scenario Analysis and Path Selection of Low-Carbon Transformation in China Based on a Modified IPAT Model. PLoS ONE 2013, 8, e77699-e77699. [CrossRef] [PubMed]

63. Ang, B.W.; Choi, K.H. Decomposition of Aggregate Energy and Gas Emission Intensities for Industry: A Refined Divisia Index Method. Energy J. 1997, 18, 59-74. [CrossRef]

64. Timmer, M.; Erumban, A.A.; Gouma, R.; Los, B.; Temurshoev, U.; Vries, G.J.D. The World Input-Output Database (WIOD): Contents, Sources and Methods. Iide Discussion Papers. 2012. Available online: https:/ /ideas.repec.org/p/lnz/wpaper/20120401.html (accessed on 28 January 2016).

65. National Bureau of Statistics of China. China Statistical Yearbook; China Statistical Press: Beijing, China, 1997-2011. 
66. National Bureau of Statistics of China. China Energy Statistical Yearbook; China Statistical Press: Beijing, China, 1997-2011.

67. BP Statistical Review of World Energy. Statistical Review-Data workbook. 2015. Available online: http://www.bp.com/en/global/corporate/energy-economics/statistical-review-of-world-energy.html (accessed on 28 January 2016).

68. Ministry of Finance of the People' Republic of China. Interim Measures for the Administration of Special Funds for the Industrialization of Wind Power Equipment. 2008. Available online: http:/ /www.mof.gov. cn/zhengwuxinxi/zhengcefabu/2008zcfb/200808/t20080822_66469.htm (accessed on 28 January 2016).

69. National Development and Reform Commission. A Notice on Improving the Electricity Price Policy of Wind Power Generation. 2009. Available online: http://www.sdpc.gov.cn/zcfb/zcfbtz/200907/t200 90727_292827.html (accessed on 28 January 2016).

(c) 2016 by the authors; licensee MDPI, Basel, Switzerland. This article is an open access article distributed under the terms and conditions of the Creative Commons by Attribution (CC-BY) license (http://creativecommons.org/licenses/by/4.0/). 